\title{
海山列に着目した遠地津波の最大波遅延要因の分析と 予報精度向上に向けての課題
}

\author{
Analysis of Later-Phase Tsunamis by Seamount Chains and Implications to \\ Far-Field Tsunami Warning
}

\author{
宗本金吾 $^{1} \cdot$ 越村俊一 $^{2} \cdot$ 今村文彦 ${ }^{3}$ \\ Kingo MUNEMOTO, Shunichi KOSHIMURA and Fumihiko IMAMURA
}

\begin{abstract}
Focusing on the scattering waves excited at seamount chains, this study aims to investigate the delay of maximum tsunami to Pacific coast of Japan by integration of numerical analysis and analytical solution by Longuet-Higgins (1967). The results imply that Emperor seamount chain is one of major factors to excite scattering waves to Japan, and the later-phase tsunamis by the magnitude 8 class earthquakes from Hokkaido, Kuril and Alutian islands possibly affect to Pacific coast of Japan. Throughout the results, we discuss the issues to improve the accuracy of tsunami forecasting.
\end{abstract}

\section{1.はじめに}

2006年千島列島沖地震津波では，海山列で発生した散 乱波の影響で, 我が国への最大波到達が地震発生後6時間 以降と大きく遅延した。この事例は, 海山で励起される 散乱波が最大波の到達を遅延させる危険性があること，散 乱波の要因となる海底地形の把握と到達時間の予測が津 波予報解除の基準を考慮する上で重要な課題である事を 示唆している．海山列で発生する津波散乱波の我が国太 平洋岸に扔ける防災上の問題に関しては，2006年千島列 島沖地震津波の伝播特性における天皇海山列の影響を数 值解析及び数值実験によって検討した越村ら (2007) の研究 や，千島海溝で発生する地震津波の後続波に関する宗本 ら（2008）の研究があるが, 太平洋で発生する津波にお ける海山列の防災上の問題を, 遠地津波の最大波遅延と いう観点から検討した例は無い。そこで本研究では，太 平洋を伝播して我が国に到達する津波に着目し, 最大波 の遅延が生じる条件を, 津波波源の位置, 地震の規模, 散 乱波の発生メカニズムとの関連で明らかにし, 我が国の 遠地津波の予報精度向上に向けた課題を整理する事を目 的にする.

具体的にはまず，太平洋に無数に存在する海山のうち, 散乱波が我が国における津波最大波の遅延という観点か ら重要な海山を, Mofjeldら（2004）が提案しているScattering Indexを用いた散乱源の特定手法や, 環太平洋の主 要なプレート境界での津波発生を想定した津波数值解析 結果, さらに海山の空間スケールや海山の位置を考慮し て特定する.

\begin{tabular}{llll}
\hline 1 & 正会員 & 工(修) & (株)アルファ水工コンサルタンツ \\
2 & 正会貝 & 工(博) & 東北大学准教授 大学院工学研究科 \\
3 & 正会員 & 工(博) & 東北大学教授 大学院工学研究科
\end{tabular}

次に, Longuet-Higgins（1967）の円筒海山モデルに基 づいた散乱波理論に基づき，天皇海山列で発生する散乱 波の特性を海山のスケール，入射波波長，入射波周期に 関して検討する。

さらに，太平洋のプレート境界型地震に基づいた数值 解析結果と波向線法を用いて描いた散乱波の走時を考慮 し, 我が国への最大波の遅延をもたらす地震津波シナリ オを明らかにする。

最後に, 以上の結果を総合し, 太平洋の津波予報解除 の基準を策定するための課題について整理する.

\section{2. 散乱源の特定}

ここでは, 太平洋に無数に存在する海山のうち, 津波 最大波の遅延を考慮した際に重要な海山を特定する。具 体的には, Mofjeldら（2004）が提案しているScattering Indexを用いて我が国近海の散乱源（顕著な散乱波を発生 させる海山地形）を調べ，その結果を数值解析によって 検証する。次に，海山のスケールや我が国との位置関係， 海山と我が国の間の海底地形の特徵などを考慮し, 我が 国太平洋岸に㧍ける最大波遅延という観点から最も重要 な散乱源を特定する.

散乱源に関して, Mofjeldら（2004）はScattring Index という指標を用いて, 散乱波が発生しやすい海底地形を 評価した. Scattering Indexの定義を以下に示す.

$$
\begin{aligned}
& S=1-T_{\min } \cdots \cdots \cdots \cdots \cdots \cdots \cdots \cdots \cdots \cdots \cdots \cdots \cdots \cdots \cdots \cdots \cdots \cdots \\
& T_{\text {min }}=\frac{2 \epsilon}{\left(1+\epsilon^{2}\right)}, \epsilon=\sqrt{H_{0} / H_{1}}
\end{aligned}
$$

ここで, $H_{0}, H_{1}$ はそれぞれ海山上の水深と海山周辺の 水深を表す. Mofjeldらはこの指標を用いて, 海山周辺の 水深が $4000 \mathrm{~m} \sim 6000 \mathrm{~m}$ の領域で散乱波の発生に関して検 
表-1 Mofjeldら（2004）による頂面水深と津波の散乱の関係

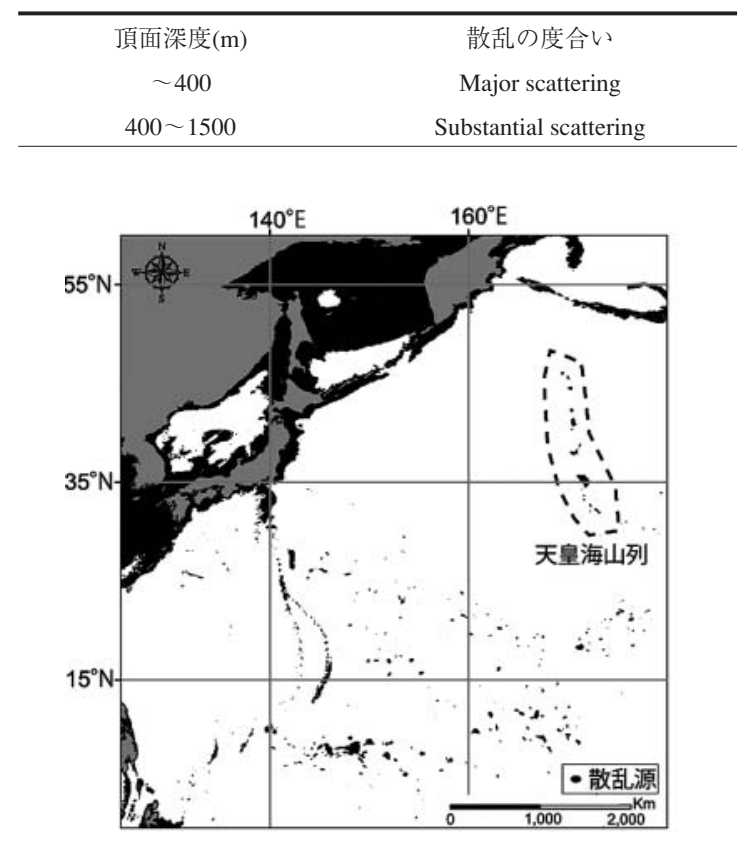

図-1 日本近海の顕著な散乱源

討を行い，その結果を表-1のようにまとめている。これ によると, 海山の頂面水深が $1500 \mathrm{~m}$ り浅い領域では散 乱波が発生しやすいことがわかる。この基準を用い, 我 が国周辺の散乱源を調べた結果を図-1に示す。この図に おいて, 白い部分は水深 $1500 \mathrm{~m}$ 以深の領域, 黒い部分は 水深 $1500 \mathrm{~m}$ 以浅の領域を表す。ただし, 水深 $1500 \mathrm{~m}$ 未満 の部分には島嶼も含む.こうして特定した散乱源は, 数 值解析結果を可視化して確認したところ顕著な散乱波を 励起することが確認された. 次に, これらの散乱源のう ち，太平洋岸での最大波遅延を考慮する際に重要な海山 を選定する．散乱源の水平スケールに関しては，海山の 水平スケールより波長が短い波が散乱しやすいことが Longuet-Higgins（1967）の散乱波の理論解によってわか っているので, 水平方向のスケールが大きい方が散乱源 として重要である. 次に, 最大波の遅延という観点から は, 散乱源は我が国に遠い方が危険であると考えられる. ここで, 図-1中の, 天皇海山列に着目すると, 天皇海山 列には水平方向のスケールが大きな散乱源があり, 我が 国から約 $3000 \mathrm{~km}$ と離れたところに存在し, さらに我が 国と天皇海山列の間には散乱源が少ない事がわかる。よ って, 最大波の遅延という観点から最も危険な海山は天 皇海山列に存在する海山であるという事がわかる.

\section{3. 海山列による散乱波の周波数特性}

ここでは, 天皇海山列で発生する散乱波の周波数特性 に関して, Longuet-Higgins（1967）の単一円筒の散乱波理
表-2 代表的な海山の比高と平均頂面深度

\begin{tabular}{ccc}
\hline 海山名 & 比高 $(\mathrm{m})$ & 平均頂面深度 $(\mathrm{m})$ \\
欽明海山 & 5000 & 500 \\
推古海山 & 5200 & $1000 \sim 2000$ \\
仁徳海山 & 5000 & $1000 \sim 1500$ \\
\hline
\end{tabular}

図-2Ｌonguet-Higginsの単一円筒モデル

論を海山列に対してあてはめて検討する. Longuet-Higgins（1967）の単一円筒海山モデルを図-2に示す．この 円筒モデルに基づいて天皇海山列の代表的な海山, 推古, 仁徳，欽明海山周辺を円筒で近似し，発生する散乱波の 振幅の理論解を比べる事で, 天皇海山「列」で発生する 散乱波の周波数特性を検討する. 図-3に天皇海山列付近 の水深, 代表的な海山を含んだ領域, 円筒でそれらの領 域をモデル化した際の円及び円の直径（R）を示す.ここ で，代表的な海山は頂面水深，円筒で近似した際の円の 直径で選定した（表-2に代表的な海山の比高と平均頂面 深度を示す). モデル化の際は, 水深 $3000 \mathrm{~m}$ 以浅の部分に 着目してモデル化を行った. 図-4に推古海山, 仁徳海山, 欽明海山周辺を円筒モデルでモデル化し，入射波周期及 び入射波波長に対する散乱波の振幅の理論解 $(|B n|)$ を示 す. $|B n|$ は以下のように定義される.

$$
B_{n}=i^{n} \cdot \frac{J_{n}(v) J_{n}^{\prime}(s v)-s J_{n}^{\prime}(v) J_{n}(s v)}{s J_{n}^{\prime}(v) H_{n}(s v)-J_{n}(v) H_{n}^{\prime}(s v)}
$$

ここで, $J_{n}, H_{n}$ は $n$ 次の第 1 種ベッセル関数と第 1 種ハ ンケル関数, 'は微分演算子である. $s$ は海山周辺海域と 海山頂部の水深比 $s=\sqrt{h_{2} / h_{1}}, v$ は海山上の津波の波数 $k_{2}$ と海山の半径 $a$ による無次元波数 $v=a k_{2}=a k_{1} / s$ である. 図-4に推古，仁徳，欽明の3つの海山モデルによる散乱波 の振幅を示す. 周期 12 分以下, 波長 $150 \mathrm{~km}$ 以下の領域に ピークが多い事がわかる。これは，この領域の周期ある いは波長の津波が, 天皇海山列に入射した場合, 励起さ れる散乱波の振幅が大きくなりやすい傾向を示している. ところで，この $150 \mathrm{~km}$ という值は，欽明海山を含む領域 を円筒で近似した際の直径に等しい.この值を天皇海山 列付近の水深 $5000 \mathrm{~m}$ における長波の波速を用いて周期に 直すと, $150 \times 1000 / \sqrt{9.8 \times 5000} / 60=11.29$ (分) となる. これより, 周期が 11 分未満, 波長 $150 \mathrm{~km}$ 以下の津波が天 皇海山列で散乱されやすいことが分かる. 


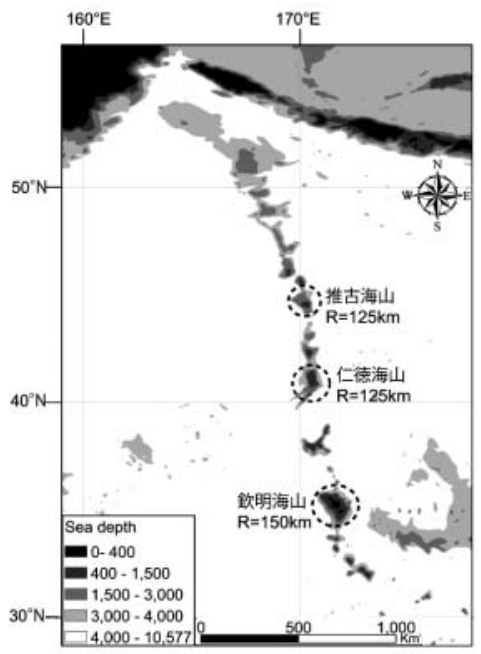

図-3 天皇海山列の代表的な海山

\section{4. 天皇海山列で発生する散乱波により最大波の 遅延が生じる津波シナリオ}

ここでは, 天皇海山列で発生する散乱波によって最大 波の遅延が生じる津波シナリオについて, 数值解析的に 検討する. 具体的には, 千島海溝, アリューシャン海溝, 日本海溝, 伊豆海溝, マリアナ海溝のプレート境界にお いて, マグニチュード8クラスの地震を想定し, 天皇海山 列で発生する散乱波が我が国太平洋岸における最大波に どのような影響を与えているか, 天皇海山列が存在する 実地形データと, 天皇海山列が存在しない仮想地形デー 夕に基づく計算波形を比較することにより検討する。こ こでマグニチュード 8 というのは，2006年千島列島沖地震 津波の事例を参考に決定し, 天皇海山列が存在しない地 形データは, 越村ら（2007）に倣い, 天皇海山列付近の 水深を一定值の $5000 \mathrm{~m}$ とする事で作成した.

図-5に本研究で検討した波源（図中の四角）の位置を 示す. 北米, 中米, チリ海溝における津波シナリオを検 討していないのは, これらの海溝で発生した津波によっ て天皇海山列で発生する散乱波が, 最大波の遅延に寄与 しないと確認されたためである。これは, 天皇海山列が, 我が国と波源の間に存在するために, 北米, 中米, チリ 海溝で発生する津波が天皇海山列に到達し, 我が国に到 達するまでの時間と, 天皇海山列で発生する散乱波が我 が国到達する時間の差が小さいことが主因である（前方 散乱). 波源モデルに関しては, 千島海溝, アリューシャ ン海溝には, それぞれの海溝で発生した地震の履歴を考 慮して, 越村ら（2007）の波源モデルを断層の基準点の 位置及び断層の走向を変えて設定し, 日本海溝, 伊豆海 溝，マリアナ海溝に関しては, 阿部・今村（2007）を参 考に以下の相似則に基づいて求めた.

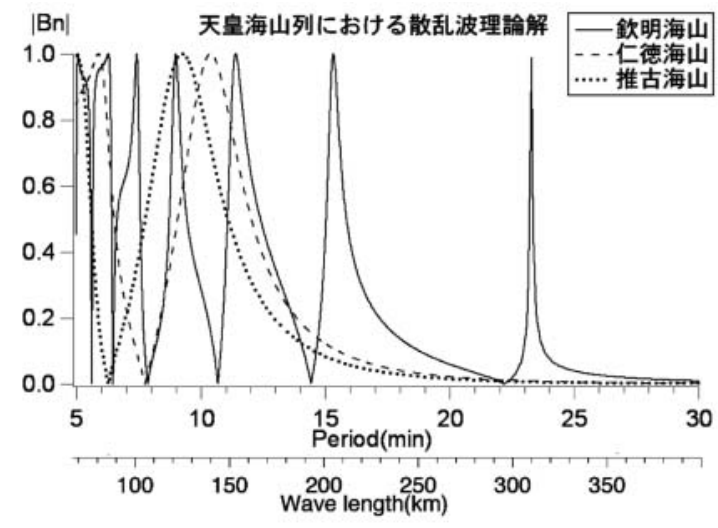

図-4 天皇海山列の代表的な海山における散乱波の理論解 $B_{n}($ モードは $n=2)$

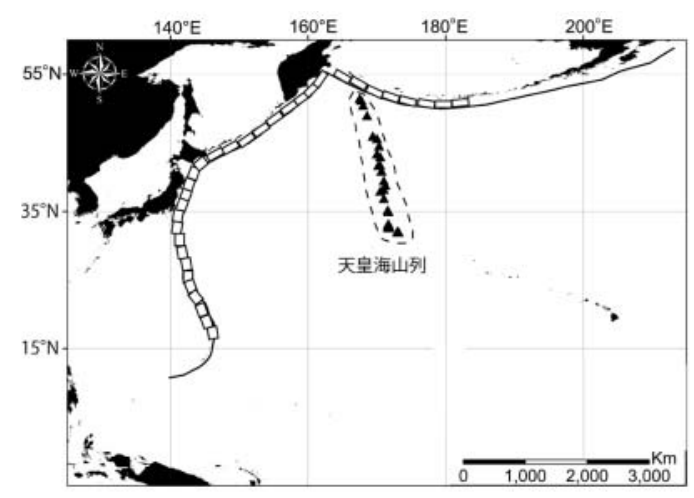

図-5 検討領域と想定した津波波源

断層長さ $L ; \log L=0.5 M-1.9$ (4)

平均滑り量 $D ; \log D=0.5 M-3.2$

断層幅 $W ; W / L=0.5$

断層の走向は海溝軸と平行になる様に設定した. 支配 方程式は線形長波理論式, 時間格子間隔は 3 秒とし. 再 現時間は 12 時間とした。地形データは, GEBCO（British Oceanographic Data Centre, 1997）の 1 分グリッドデータ を用いた。

アリューシャン海溝での検討結果の一例を図-6と図-7 に示す。図-6の実線は, 天皇海山列が存在する実地形デ ー夕に基づく計算波形, 点線は天皇海山列が存在しない 仮想地形デー夕に基づく計算波形である. 図-6の実線に おいて, 地震発生後約 8 時間後に見られるのが最大波で あり, 最大波において実線と点線の波形に違いが見られる. これより, 天皇海山列で発生する散乱波の影響で, 最大 波の遅延が起こりうる事がわかる。ここで, 図-6におい ては, 天皇海山列で発生した散乱波の到達後に，2006年 


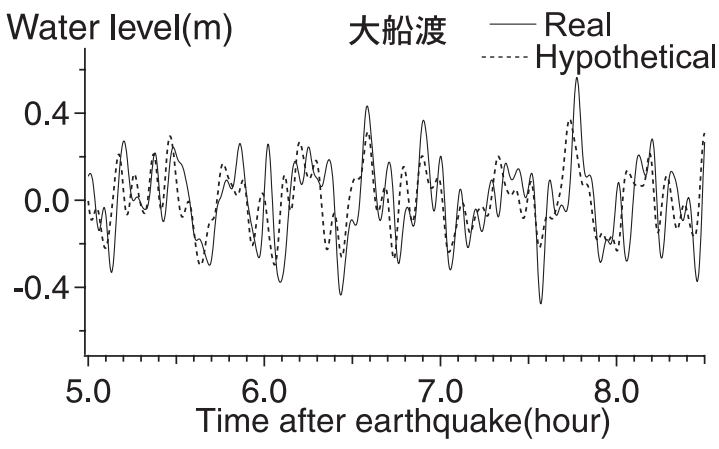

図-6 アリューシャン海溝における検討の一例 (波形) 実線： 実地形データに基づいたもの, 破線:仮想地形データに基 づいたもの

千島列島沖地震津波の事例のように短周期成分の増加が 見られない. 宗本ら（2008）は，千島海溝で発生した津 波において，散乱波が後続波として卓越する場合，短周 期成分の増加が起こるとしている。この散乱波到達後の 周波数特性の違いは，我が国と天皇海山列と波源の位置 関係の違いであると考えられる。つまり，千島海溝で発 生した津波によって, 天皇海山列で発生する散乱波は, 波源から一度我が国とは別の方向へ放出され，それが天 皇海山列で散乱して我が国に到達した成分であるが，ア リューシャン海溝のこの事例においては, 波源, 我が国, 天皇海山列の位置関係により，海山上で励起される成分 と, 励起されない成分の両方が我が国に来襲するため, 千島海溝における事例のような，顕著な周波数特性が見 られないのだと考えられる。

このケースの最大波高分布図を, 図-7に示す。この事 例では，指向性の関係で津波エネルギーが天皇海山列に 到達しているのがわかる，そのため，散乱波の影響が比 較的大きく出たのであろう。ここでは図-8に波源から我 が国へ直接来襲する津波の走時（a）と，天皇海山列で発 生する散乱波の走時（b）を示す。図-8から，波源で発生 した津波は 3 時間で天皇海山列最南端に到達し，そこで発 生した散乱波は約 7 時間後に東北地方太平洋沿岸部に到達 する事がわかる。これは，図-6における最大波出現時間 と良く一致する。このようにアリューシャン海溝沿いで 想定した津波のシナリオについて，実地形データと仮想 地形デー夕に基づいた波形の違いと，最大波高分布図及 び，波向線法に基づいた津波の走時を踏まえた検討をした 結果, アリューシャン海溝では, 東経 $173^{\circ}$ から $180^{\circ}$ 付近で 津波 が発生すると天皇海山列の影響で最大波が遅延しう る事，その際の最大波は東北地方沿岸部で7時間後以降に 来襲する危険性があることがわかった.

次に, 日本海溝で同様の検討を行った結果，東北地方 の沖合で津波が発生した場合，指向性の関係で天皇海山 列に比較的強い津波エネルギーが天皇海山列に到達して

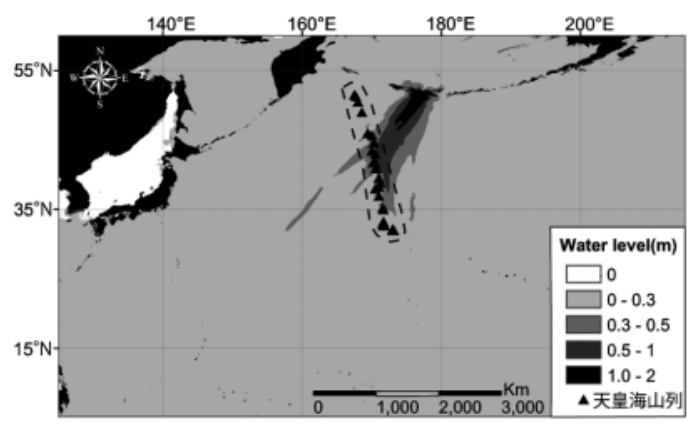

図-7 アリューシャン海溝で発生する津波の最大波高分布図の 一例

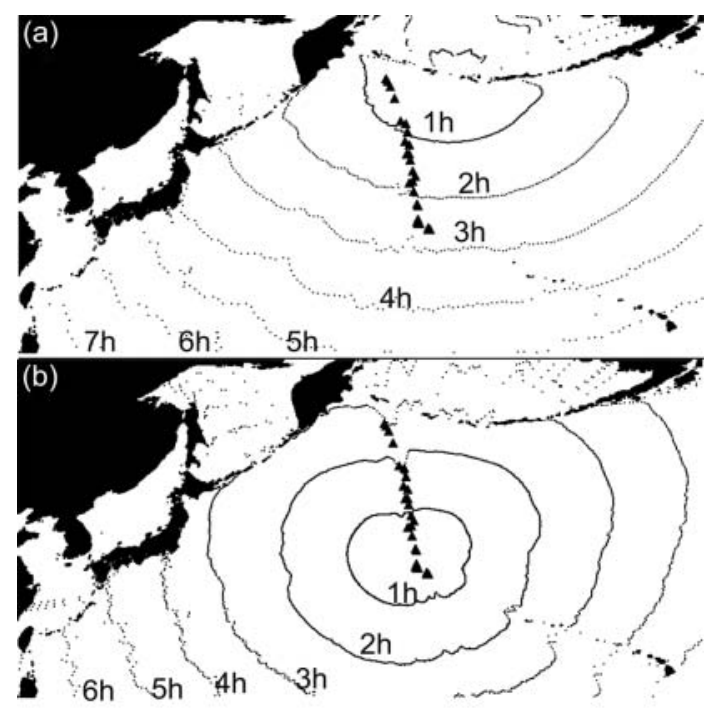

図-8 波源から我が国に到達する津波の走時（a）と天皇海山列 中最大規模の欽明海山付近で発生した散乱波の走時（b)

いる事がわかった。しかし，天皇海山列の有無が計算波 形に与える影響を調べたところ，波源の近くの計算波形 出力地点では，天皇海山列の影響が殆ど無かった。これ は，天皇海山列で発生する散乱波の影響よりも，波源が 近い事による振動の継続影響の方が強かったと考えられ る.この事例のように, 東北地方の沖合で想定したケー スでは，天皇海山列に強い津波エネルギーが到達するこ とがわかった。その場合，波源付近では天皇海山列で発 生した散乱波の影響は小さいが，波源から離れた場所で は，散乱波の影響で振動が長期化することが懸念される. 最後に, 伊豆海溝, マリアナ海溝で発生する津波に関 しては，天皇海山列で発生する散乱波の影響は極めて小 さくなる事がわかった。

以上の検討と千島海溝に関する検討を行った宗本ら （2008）の結果を総合し，我が国への最大波の遅延をも たらす津波波源の位置を特定した結果を図-9に示す。天 皇海山列で発生する散乱波の影響で最大波の遅延が起こ 


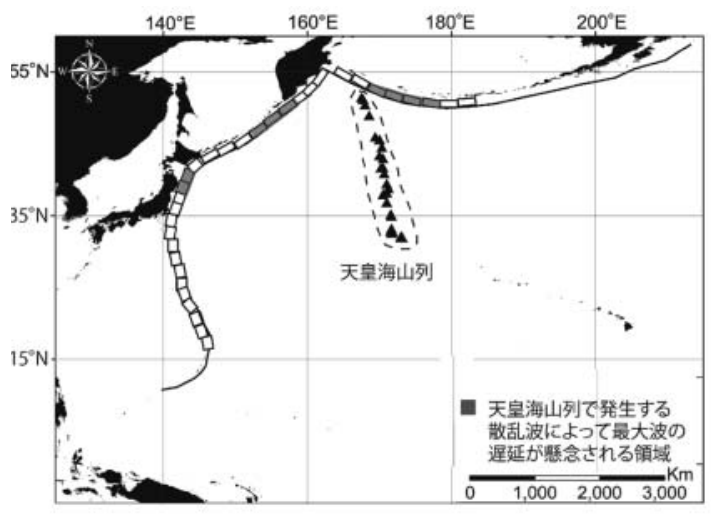

図-9 我が国への最大波の遅延が起こりうる波源域

りうるのは, マグニチュード 8 クラス以上の地震による 津波が, 千島海溝では北緯 $46^{\circ}$ から $49^{\circ}$, アリューシャ ン海溝では, 東経 173 から $180^{\circ}$, 日本海溝では東北地方 の沖合で津波が発生した時である。ただし，東北地方の 沖合で津波が発生した場合には, 東北・北海道太平洋岸 など比較的波源の近くの地点では散乱波の影響が小さい が, 波源から遠く離れた場所では, 散乱波の影響で振動 が長期化し，最大波の遅延が生じることが懸念される.

\section{5. 予報精度向上のための課題}

現状の津波予報・警報システムでは，2006年千島列島 沖地震津波や, 2009年パプアニューギニア地震津波のよ うな, いったん海面震動が収まるかの様に見えて, その 後, 海山や島などの散乱波によって最大波が大きく遅延 するような事例では，予報解除の判断を間違えてしまう 危険性がある。これは，あらかじめ後続波として来襲す ることが予想される波動の性質や, 最大波来襲時刻など が整理されていない事から起きると考えられる，そこで 本研究では, 遠地津波に関して, 天皇海山列で発生する 散乱波に着目して, 地震の規模や, 波源の位置, 最大波 の来襲時 刻等について整理する事を試みた. 他の様々な 最大波遅延要因に関しても同様の検討をしていく必要が あると考えられる. 特に, 波源の位置から後続波として 卓越する津波の有無, 後続波の減衰特性についての経験 則を整備し，最大波の来襲時間についての予測精度を上 げることが津波予警報システムへの信頼性向上に不可欠 である。

\section{6. おわりに}

本研究で得られた主な結論を以下に列挙する.

Mofjeldら（2004）が提案しているScattering Indexを用 いた散乱源の特定手法と数值解析結果をふまえ, 我が国 における最大波の遅延という観点から，最も需要な海山 は天皇海山列である事がわかった。

Longuet-Higgins（1967）の単一円筒海山理論に基づき, 天皇海山列で発生する散乱波の周波数特性を理論的に検 討した。 その結果, 天皇海山列では, 周期 11 分以下, 波 長 $150 \mathrm{~km}$ 以下の津波が散乱しやすいことがわかった.

天皇海山列で発生する散乱波によって最大波の遅延が 起こることが懸念される津波シナリオを特定した.

遠地津波予報解除の基準を策定する際には，特に天皇 海山列に入射する津波の波高と周波数特性に留意し, 津 波波源の位置, 規模と, 我が国への伝播途上で観測され る津波波形のリアルタイム処理で得られる周波数特性, および散乱波の走時との関連で予報解除の基準を策定す ることが可能である，そのためのデータベースを，観測 実績や数值解析を用いて構築することが, 遠地津波の予 報精度向上に繋がることがわかった。

謝辞：本研究の一部は，科学研究費補助金基盤研究 (A) （代表：目黒公郎, 課題番号：18254002）および平成 20 年 度産業技術研究助成事業（代表：越村俊一, プロジェ クトID：08E52010a）の補助を受けて実施された。ここ に記して謝意を表する。

\section{参 考 文 献}

阿部郁男・今村文彦（2007）：津波データベースを利用した 簡易的な津波減衰指標の提案, 海岸工学論文集, 第 54 巻, pp.186-190.

越村俊一 - 宗本金吾 - 大家隆行 - 柳沢英明 - 阿部郁男 - 今村 文彦（2007）：2006年千島列島沖地震津波の伝播特性に おける天皇海 山列の影響評価, 海岸工学論文集, 第 54 巻, pp.171-175.

宗本金吾・越村俊一. 今村文彦（2008）：千島海溝で発生す る津波の後続波に関する研究, 海岸工学論文集, 第 55 巻, pp.296-300.

British Oceanographic Data Centre (1997), The Centenary Edition of the GEBCO Digital Atlas (CD-ROM)

Longuet-Higgins,M.S.(1967):On the trapping of wave energy round islands, J. Fluid Mech., 29(4), pp. 781-821.

Mofjeld, H. O., C. M. Symons, P. Lonsdale, F. I. Gonzalez and V. V. Titov (2004); Tsunami Scattering and Earthquake Faults in the Deep Pacific Ocean, Oceangraphy, 17(1), pp.38-46. 